\title{
STUDYING ADMINISTRATIVE CORRUPTION BASED ON BRANCH ANALYSIS IN PATHOLOGY THEORY AND SUGGESTING STRATEGIES FOR CONTROLLING IT (A CASE STUDY ON ADMINISTRATIONS OF TEHRAN PROVINCE)
}

\author{
Mahtab Jafari \\ University of Tehran (Tehran, Iran)
}

Administrative corruption is largely influenced by economic, political, social, cultural, and judicial systems and also, it has negative impacts on the legitimacy of political systems and the performance of administrative systems. Therefore, the aim of the current study is to identify the causes of the emergence and the prevalence of administrative corruption and to provide appropriate strategies for controlling and restricting the scope of administrative corruption. Hence, this research is of descriptive-analytical type and it is based on data collected by field methods. It should be noted that consistency and validity of the questionnaire has been examined with Cronbach's alpha and factor analysis, respectively. Then, non-parametric tests including binomial test and Friedman test have been used for testing the hypothesis. Ultimately, the results of this study showed that there are several factors such as lack of professional conscience, lack of adherence to ethics in the society, the sense of economic inequality in government employees in comparison with those in the other sectors, complexity of laws, etc., have significant influence on the emergence of administrative corruption. Also, some other factors such as existence of an efficient financial control system, effective administrative control, establishing some independent agencies for resolving the administrative corruption, intensification of the penalties, depoliticizing the administrative system, and applying efficient regulations can be effective in controlling and preventing the administrative corruption.

Keywords: administrative corruption, controlling the administrative corruption, pathology theory, threebranch analytical model, administrations of Tehran province.

\section{ИЗУЧЕНИЕ АДМИНИСТРАТИВНОЙ КОРРУПЦИИ НА ОСНОВЕ ТРЕХФАКТОРНОЙ МОДЕЛИ В КОНТЕКСТЕ ТЕОРИИ ОРГАНИЗАЦИОННОЙ ПАТОЛОГИИ И ВЫРАБОТКА МЕРОПРИЯТИЙ ПО ЕЕ СНИЖЕНИЮ (НА ПРИМЕРЕ ПРОВИНЦИИ ТЕГЕРАН)}

\author{
Махтаб Джафари \\ Тегеранский университет (Тегеран, Иран)
}

Административная коррупция в значительной степени зависит от экономической, политической, социальной, культурной и судебной систем. Она оказывает также негативное воздействие на легитимность политических систем и эффективность административных систем. В этой связи, целью настоящего исследования является выявление причин возникновения и распространения коррупции и разработка соответствующих стратегий контроля и ограничения ее масштабов. Исследование носит описательно-аналитический характер и основано на данных, собранных полевыми методами. Следует отметить, что согласованность и обоснованность используемого опросника были рассмотрены с помощью альфы Л. Кронбаха и факторного анализа соответственно. Затем для проверки гипотезы были использо- 
ваны непараметрические тесты, включая биномиальный тест и тест М. Фридмана. В конечном итоге результаты данного исследования показали, что существует несколько факторов, оказывающих значительное влияние на возникновение коррупции, в числе которых отсутствие профессионального сознания, упадок моральных ценностей в обществе, чувство экономического неравенства в сфере государственной службы по сравнению с другими секторами, сложность законов и т. д. Вместе с тем некоторые факторы, такие как наличие эффективной системы финансового и административного контроля, создание независимых структур для регулирования уровня коррупции, усиление санкций, деполитизация административной системы и применение эффективных правил, могут быть эффективными в борьбе с коррупцией.

Ключевые слова: административная коррупция, контроль административной коррупции, теория патологии, трехфакторная модель, администрация провинции Тегеран.

I ntroduction. In all societies, administrative system is seen as a functional and administrative aspect of government, and is the way of communication between government and people. All around the world, administrative systems are so important that people's evaluation of their political system is based on their administrative system and, if we consider types of organizations and the administrative institutions of a government and their functions as a way of differentiating the governments from each other, it will not be exaggeration. The philosophy behind the existence of the administrative system in every society is to enable a government to perform its duties for people in different political, economic, social and other areas and for its general purposes. It is clear that performing these duties will ultimately lead to legitimacy and survival of political systems, in addition to ensuring social organization, order, and stability.

Certainly, it is possible to achieve these goals only when the society has a clear and efficient administrative system. Obviously, if the administrative system loses its efficiency or gets corrupted for any reason, it can be expected that the system becomes one of the fundamental holes in the government, resulting in a disruption in relationships between government and society. This will lead to disastrous consequences for political and social stability.

Administrative corruption is largely influenced by economic, social, judicial and cultural systems in any society and, at the same time, has negative effects on the legitimacy of the political system and the efficiency of administrative system. Also three facts about administrative corruption include inclusiveness, harmfulness, and controllability. Hence, the matter of administrative corruption and inefficiency of administrative systems has been a major concern for governments and political and social experts in all countries of the world. The remnants of the first governments formed in China and India represent the long history of governments' concern about the misuse of government jobs. Nowadays, along with the development of government activities in the administration of societies, this concern has become more important so that international agencies and institutions have also paid attention to it. Also, these agencies put practices on their agenda to deal with the administrative corruption in countries. It should be noted that the importance of this issue in Iran is even more than this, as Iran is the only country in which political system and its legitimacy are based on values and people's religious beliefs. Therefore, the purpose of this study is to address this problem and to control it.

According to what was stated, the research questions in this study for identifying the causes and prevalence of administrative corruption and providing appropriate strategies for controlling and restricting the scope of administrative corruption are: "Is there a significant relationship between administrative corruption and factors including economic situation of employees, cultural characteristics of society, organizational characteristics, quality and quantity of laws, and individual characteristics of employees?", "Is there a significant relationship between controlling and monitoring methods and the reduction of administrative corruption?", "What are the most effective control methods?" The hypotheses corresponding to the questions mentioned above are as follows (respectively): "There is a significant relationship between the economic situation of employees, cultural characteristics of society, organizational characteristics, quality and quantity of laws, individual characteristics of employees and administrative corruption", and also "There is a significant relationship between controlling methods and the reduction of administrative corruption".

Research Methodology. The present research is a descriptive-analytic type and in terms of applied research. So, for analyzing and evaluating research hypotheses, in addition to library and electronic resources (documentary methods), the findings of the questionnaire (field method) have also been used. Since the administrative system is the domain of research; because of wide scope of this domain, the statistical society of the research was selected with a 
focus on the staff of 51 departments from 96 general offices in Tehran province, and Obtained relevant information. Because of the considerations of some agencies, it was not possible to study the total number of employees of all the departments in the statistical population; for the sample size determination, the Cochran formula was used for an unlimited society, which is as follows:

$$
N=\frac{z^{2} \times p q}{d^{2}},
$$

$\mathrm{d}=$ Allowed mistake (usually $\mathrm{d}=0.05$ );

$\mathrm{Z}=$ for a $95 \%$ confidence level is equal to 1.96 ;

$\mathrm{p}=$ ratio of the desired attribute (the value of $\mathrm{p}$ can be obtained through an approximate estimation of previous studies with a preliminary study, or the value of $\mathrm{p}=0.5$, which gives the highest possible volume);

$$
q=(1-p)(i b i d) \text {. }
$$

Therefore, the sample size was determined as 384 people with $95 \%$ of confidence level. Then, a questionnaire was prepared and given to a number of employees of each of the offices that were selected in a simple random manner. It should be noted that since the present study focuses on a pathology in the administrative system of the country, the research questionnaire was prepared in two parts. The first part of 14 questions is based on a three-branch model in the pathology theory and examines the causes of corruption. Thesecond part, which includes 6 questions, asks for the most effective methods of controlling corruption. Nonparametric tests, binomial test and Friedman tests were used to check the hypotheses. The questionnaire is based on the Likert spectrum and the value of the options is from 1 to 5 . So, the score of 1 is very low, and the score of 5 is allocated to the very high. In the binomial test on the basis of the spectrum the index or average firstly is determined. Then the number of respondents higher than the index and the number of respondents lower than the index are determined and so the hypothesis is confirmed or disapproved. In the equation used in the binomial test $\mathrm{P}$ is the probability of occurrence of a state (the success or confirmation of the hypothesis), and $\mathrm{q}$ is the probability that the desired state is not fulfilled (hypothesis failure or disapproval). Friedman's test was used to rank the hypotheses, as well as to rank the causes and methods of corruption control.

It should be noted that before the questionnaires were given to the respondents, factor analysis was used to determine the validity of the questions. The result obtained with this method shows that the items have the necessary validity to measure the variables of the research. Then, questionnaires were tested by Cronbach's alpha coefficient test to measure their reliability. As a result of this test, the alpha coefficient was 0.711 . Since the valid coefficient is 0.7 or higher, the coefficient obtained shows that the questions have a satisfactory reliability.

Theoretical basis. Gunnar Mirdal believes that corruption is applicable to diverse cases of deviation or exercise of personal power and illegitimate use of a job position [1: 15]. McMullen argues that corruption occurs when a government official accepts bribes for doing business [9:333]. In Theobald's view, corruption is the unlawful use of administrative and governmental authority for personal gain. Finally, the World Bank and the Transparency International consider corruption to be a public authority (private power) for private gain [14:133]. Also in the United Nations Convention against Corruption, the following acts are considered as examples of corruption: "The misuse or destruction of public and governmental property and property by public officials, abusers or traders by public officials, the containment of proceeds from committing corruption, misuse of responsibility, for the purpose of personal exploitation, the illegal exploitation of property, Abuse of the official authority, the use of classified or confidential information for the purpose of personal gain, alteration of the use and misuse of public property, the acquisition of illicit profit and corruption in the private sector [3:247].

Levels of administrative corruption. Corruption is prevalent on two levels:

The first level is the corruption that most senior officials and senior government officials are engaged in, so as political parties and political bits. The interpretation of "white collar" can be applied at this level. These types of corruption occur here - in "import", "auctions", "tenders", "macro and foreign domestic purchases", "parts related to the sale of underground resources' and "large construction projects' [10:31].

The second level is often made up of low-level employees, and this kind of corruption includes "public bribes", "illegal exploitation", and so on. Corruption at the second level is principally associated with the private sector and the general level of society [10]. In addition to the division above, another division is presented about the levels of corruption, which is briefly discussed:

1. Incidental corruption and systematic corruption (acute). The degree of corruption in different societies varies, from varying degrees to the most extreme degree, if corruption is low, it can easily be discovered and punished and destroyed. But when corruption becomes commonplace in society, it is more likely that the corruption and punishment of perpetrators would be reduced. The motivation to tackle corruption increases because unlike casualties, the parties are reluctant to report otherwise to competent authorities. Wherever corruption is regulated, institutions, codes, 
and codes of conduct are consistent with the misplaced patterns of bureaucrats and corrupted government agents. In this case, bribes can also slow down the processing of files. One of the thinkers, Herbert Werlin, likened the mistakes made in the football game, with the referee penalizing the player by showing a card. Systematic corruption is like encouraging violence in the game of football, so that the game changes nature and becomes a factor in the conflict. This form of corruption threatens economic development in many developing countries [1:19].

2. Organized corruption or individual corruption. In the administrative system where corruption is organized, investors know who to bribe and how much to pay. They are confident that they will obtain the necessary permissions for their enterprises. Organized corruption occurs when the amount (bribe) required and the recipient is determined, and payment of the payment ensures the execution of the order by the bribe taker. Some argue that organized corruption is less harmful, since in such system a corrupt bureaucrat calls for a firm share of the firm's profits, and it benefits the firm. In individual corruption, investors have to bribe several officials and there is no guarantee that they will not be given more bribes and that they will receive the necessary permits. System corruption is organized and widespread at all levels of government, with both government officials and politicians in almost all government agencies. System corruption is, in fact, a political phenomenon, in which government agents plan to exploit their administrative position to transfer illegitimate interests to themselves and their. Indeed, the group will seek to channel the flow of illicit benefits through formal channels to the desired direction by extending the government's duties in financial matters, regulating the market and overseeing it, and undertaking important services, as well as removing or weakening economic competition. (ibid).

3. Macro corruption or micro corruption. Corruption at macro level is completely different from micro-level corruption. The corruption of state officials, ministers and high-ranking officials is called macro corruption and the corruption of staff, such as policemen and customs officials, is called micro corruption. Without controlling macro corruption, there is no hope of solving the problem of micro corruption. Macro corruption is a corruption committed by top-level administrative officials in a group, with a significant amount of money. The perpetrators of this kind of corruption are part of the white-collar group of perpetrators and are the owners of power. Although they bring in irreparable losses to the community, they are less prosecuted and punished by the justice system. This group by having "protected" or "escaped" ability is basically immune to pursuit. Studies show that in many countries, administrative corruption in the middle and lower levels of the administrative system largely depends on the degree of corruption among policy makers and senior staff. If a part of the governing body is corrupted, it needs the help of middle managers to achieve corrupt revenues on the one hand and, on the other hand, it has to weaken the regulatory and audit institutions, the press and the role of the judicial authorities [12: 44].

Causes of administrative corruption. Investigations on the phenomenon of corruption have revealed the complexity and widespread causes of the formation of this phenomenon. In general, the main causes of this phenomenon can be classified into three groups:

A) Environmental causes. Among these categories of factors that influence the emergence and corruption of the administrative system, they can be classified into two categories of economic and cultural factors, which in brief are: degree of relativity in society, unyielding society towards ethical standards, as well as economic problems in society like the disparity between the rate of growth of inflation and the growth rate of employees' salaries, the feeling of economic inequality of government employees compared to other sectors and the lack of additional benefits for employees. Generally, in the current administrative system, the appointment and assignment of corporate affairs based on a comrade or a bribe has become commonplace and the collusion between wealthy people, politicians and administrative bureaucracy agents has been accepted for crossing administrative office filters as a result, corruption occurres, especially at the macro level of society [11: 48].

B) Behavioral Causes

These include: lack of work conscience, individualism-based morale, employee risk aversion, customer familiarity with laws and regulations, etc. In general, in all countries, especially the developed countries, for administrative and organizational posts, the conditions for the recognition of which are the selection and appointment of individuals based on those conditions, In the content of administrative and government office situations, it is partly attributed to the personality characteristics of the manager, its reason for refers to importance and role of managerial personality traits in organizational behaviors that show themselves, If, on the basis of a bribe, a person is chosen for a job that does not have the conditions, then corruption is inevitable (ibid.)

C) Structural causes. One of the facts of the current administrative system is that administrative units usually face a lot of unrealistic or unnecessary rules. And the ambiguities surrounding administrative procedures and current standards of work make it possible for agents to make arbitrary decisions and actions. In addition, complicated 
administrative processes are encouraging customers to offer bribes to expedite work. On the other hand, the low salaries of employees in the social services sector are due to the gradual decline in their resistance and their subsequent habitual acceptance of these proposals. Among the structural causes affecting corruption are:

- Structural and organizational issues such as inappropriateness of personnel and facilities with the goals and activities of the organization resulting from the limitation of human and financial resources or the weakness of internal control systems.

— Situational and executive problems of applicable laws and regulations.

- Inappropriateness of laws and regulations with the needs and requirements of the society, changes in the laws, and sometimes their conflict with each other, as well as the ambiguity or brief in the texts of some rules and regulations and the ability to interpret them and their various interpretations.

- Issues and problems related to the attraction, training and maintenance of expert and efficient people.

- Performance of previous managers and their impact on the current performance of the executive organization [11:48].

The consequences of administrative corruption. Due to the complex nature of corruption, its scope is very wide, negative and destructive. Accordingly, the most important consequences are:

- administrative corruption has been caused disrupting the combination of government expenditures, because corrupt politicians shift resources to sectors where their performance become profitable [7: 42]. In general, corruption by weakening incentives, undermining existing institutions, and unjust distribution of resources, causes social, political and economic losses [3: 258].

- administrative corruption undermines legitimacy and effectiveness of governments and endangers the stability and security of societies. In addition, it undermines the values of democracy and morality, thereby blocking political and social development [15].

- -administrative corruption increases inequalities, because resources are often allocated to sectors that have the power to repay it. In other words, people with better financial and positional abilities will attract more resources, which will lead to greater class divisions [5].

- administrative corruption will lead to wasting investment in human resources, diminishing moral virtues and creating negative values in the organization.
- administrative corruption prevents the growth of healthy competition and undermines efforts to reduce poverty and social exclusion (ibid).

Study of administrative corruption in different countries and Iran according to the report of the Transparency International Organization. The Transparency International Organization is a nonprofit organization founded in 1993 in Germany, with its center in Berlin. Each year, the organization produces and publishes a report on corruption and government in the world. In the report, corruption is defined as "abuse of power for personal gain" and the views of the people and experts in this field are the basis for evaluation. The organization has affiliated centers in a number of countries in the world, each independently assessing the internal conditions of their countries and bringing the result to the central organization. The goal of Transparency International is to fight corruption in government institutions as well as private institutions and issues such as bribery, lawbreaking, and other cases of abuse of power are monitored at various government and economic levels [17].

Accordingly, we will attention to the report of International Transparency Organization in 2015, in which countries in the world ranked from 1 to 167. In corruption perceptions index the worst cases of corruption is showed with 0 points and the healthiest part of public sector with a score of 100. At the 2015 table, Denmark with a score of 91 is at the top of the table and has the healthiest public sector [18]. Somalia and North Korea have been declared the 8th most corrupted countries in the world. In this assessment, corruption in the Asia-Pacific region is increasing, in Saharan Africa is deteriorating and declining in the region of Europe and Central Asia [19].

Similarly, Finland with a score of 90, Sweden with a score of 89 , New Zealand and Norway with a score of 87 , Switzerland with a score of 86 , Singapore with a score of 85 , Canada with a score of 83 and Germany with a score of 81 are at the top of the table. The UK with 81 points has $10^{\text {th }}$ place and the United States with 76 points $-16^{\text {th }}$. Japan with score 75 is $18^{\text {th }}$, France with 70 is $23^{\text {rd }}$, China with $37-83^{\text {rd }}$, Russia with 29 $119^{\text {th }}$ place. Jordan with score 53 is $45^{\text {th }}$, Saudi Arabia with score 52 is $48^{\text {th }}$ and Kuwait with score 49 is on $55^{\text {th }}$ place [18]. It should be noted that in the Middle East and Islamic countries, Qatar has gained the best indicator in terms of lack of administrative and financial corruption and has gained the 71st place. After Qatar, the United Arab Emirates has gained score $71^{\text {st }}$ place with score 23 [19].

In the meantime, we need to report to the International Organization for Transparency on Corruption in Iran over the years; According to the 2003 International Transparency Report, Iran ranked 78th in 133 countries, in 2004, among 147 countries 
ranked 87th, In 2005, among 159 countries ranked 93th, in 2006 ranked 105th, in 2007 it was 131th, in 2008 the rating was 141 th, in 2009 the rating was 168th, in 2010 it was 146th, in 2011 it was 120th, In 2012, with a score of 28 was 133th, in 2013 with a
25 -point rating was 144 th, in 2014 with a score of 27 points rated 136th And in 2015 with a score of 27 points out of 100 points ranked 130th and with Cameroon, Nepal, Nicaragua, Paraguay and Ukraine was in a same row [18].

The most corrupted countries in the world in terms of the administrative system

Table 1

\begin{tabular}{|l|lr}
\hline RANK & COUNTRY/TERRITORY & SCORE \\
\hline 83 & Colombia & 37 \\
\hline 83 & Liberia & 37 \\
\hline 83 & Sri Lanka & 37 \\
\hline 88 & Albania & 36 \\
\hline 88 & Algeria & 36 \\
\hline 88 & Egypt & 36 \\
\hline 88 & Indonesia & 36 \\
\hline 88 & Morocco & 36 \\
\hline 88 & Peru & 36 \\
\hline 88 & Suriname & 36 \\
\hline 95 & Armenia & 35 \\
\hline 95 & Mali & 35 \\
\hline 95 & Mexico & 35 \\
\hline 95 & Philippines & 35 \\
\hline 99 & Bolivia & 34 \\
\hline 99 & Djibouti & 34 \\
\hline 99 & Gabon & 34 \\
\hline
\end{tabular}

\begin{tabular}{|c|c|c|}
\hline 103 & Moldova & 33 \\
\hline 107 & Argentina & 32 \\
\hline 107 & Belarus & 32 \\
\hline 107 & Côte d'lvoire & 32 \\
\hline 107 & Ecuador & 32 \\
\hline 107 & Togo & 32 \\
\hline 112 & Honduras & 31 \\
\hline 112 & Malawi & 31 \\
\hline 112 & Mauritania & 31 \\
\hline 112 & Mozambique & 31 \\
\hline 112 & Vietnam & 31 \\
\hline 117 & Pakistan & 30 \\
\hline 117 & Tanzania & 30 \\
\hline 119 & Azerbaijan & 29 \\
\hline 119 & Guyana & 29 \\
\hline 119 & Russia & 29 \\
\hline 119 & Sierra Leone & 29 \\
\hline 123 & Gambia & 28 \\
\hline
\end{tabular}

\begin{tabular}{|l|lr}
\hline RANK & COUNTRY/TERRITORY & SCORE \\
\hline 123 & Madagascar & 28 \\
\hline 123 & Timor-Leste & 28 \\
\hline 130 & Cameroon & 27 \\
\hline 130 & Iran & 27 \\
\hline 130 & Nepal & 27 \\
\hline 130 & Nicaragua & 27 \\
\hline 130 & Paraguay & 27 \\
\hline 130 & Ukraine & 27 \\
\hline 136 & Comoros & 26 \\
\hline 136 & Nigeria & 26 \\
\hline 136 & Tajikistan & 26 \\
\hline 139 & Bangladesh & 25 \\
\hline 139 & Guinea & 25 \\
\hline 139 & Kenya & 25 \\
\hline 139 & Laos & 25 \\
\hline 139 & Papua New & 25 \\
\cline { 1 - 2 } & Guinea & \\
\cline { 2 - 3 }
\end{tabular}

\begin{tabular}{l|lr}
1147 & $\begin{array}{l}\text { Democratic } \\
\text { Republic of the } \\
\text { Congo }\end{array}$ & 22 \\
\hline 147 & Myanmar & 22 \\
\hline 150 & Burundi & 21 \\
\hline 150 & Cambodia & 21 \\
\hline 150 & Zimbabwe & 21 \\
\hline 153 & Uzbekistan & 19 \\
\hline 154 & Eritrea & 18 \\
\hline 154 & Syria & 18 \\
\hline 154 & Turkmenistan & 18 \\
\hline 154 & Yemen & 18 \\
\hline 158 & Haiti & 17 \\
\hline 158 & Guinea-Bissau & 17 \\
\hline 158 & Venezuela & 17 \\
\hline 161 & Iraq & 16 \\
\hline 161 & Libya & 16 \\
\hline 163 & Angola & 15 \\
\hline & $\sim$ & .1 \\
\hline
\end{tabular}

Reference: International Transparency International Report, 2015

Theoretical Framework. Organizational pathology means identifying the causes and roots of factors that contribute to the emergence of the crisis in various phenomena, and these factors can disrupt the process of growth and efficacy of phenomena. In other words, pathology, problem resolution, and scientific focal point are essential for determining the steps needed to improve the performance of the organization. Pathology requires a systematic approach to the whole process, and aims at identifying the nature and type of problem that is emerging and needs to be addressed [16:97]. Similarly, organizational pathology is a group process and, in this sense, needs to have similar goals and approaches. Individuals should be actively involved in running processes. Therefore, organizational pathology requires changes and new ways of adopting. Such changes can help to improve the future performance and development of the organization [13].

Organizational Pathology usually requires the examination of two broad areas. The first one identifies the constituent elements of the organization, which include the sectors, departments, products, and the relationships between the factors and their interactions. The second area is pathology based on organizational processes that include communication networks, group problem solving, decision-making, leadership and power, planning and targeting methods, conflict management and competition. It should also be noted that today's economic, social and political changes are among the factors of rapid change in organizations [8]. Therefore, organizational pathology plays an important role in recognizing organizational issues, identifying its causes, choosing the right solutions, regardless of whether the process of change has been planned or emerged. In the absence of a robust pathologist consultant organizational leaders are likely to identify problems or make mistakes. This affects the readiness of the organization to make changes [8].

Causative agents and types of injuries. Normally, the outside factors cause irregularities and disruptions in living organisms, the order of internal structure and their internal processes. Organizational damage is categorized into three levels: qualitative, critical, and hazardous:

1. Preliminary damage. The only major risk of this kind of damage, in this regard, is that if not properly understood, addressed and repelled, becomes critical damage. Most of these damages can be recognized and prevented. 
2. Critical Damage. Damage is caused by nondealing with initial damage in the organization. These types of damage are evident in the "structural, behavioral, and underlying" branches, and can be expressed scientifically.

3. Harmful and deadly injuries. These types of injuries are the most dangerous types of organizational damage that, if not well understood, will cause the organization to be destroyed, such as the vulnerability of strategic decision makers. In this kind of damage, not only the growth and development is disturbed, but the life and survival of the organization is also seriously endangered. These three types of organizational damage are interconnected and, if not properly understood and treated, one becomes the other [4: 62-63].

Organizational Pathology Patterns. Pathology is based on the understanding of the organization's work.
The intellectual frameworks that apply the organizational change factors used for evaluation the organization are called "pathological patterns". Pathological patterns play a decisive role in the organizational transformation program [20:11]. By recognizing the pathological patterns, it is possible to construct and institutionalize them according to organizational requirements. So, by observing a problem in the organization from a systematic viewpoint, one can examine the interactions between different organizational units and understand the roots of the problem, and with preventive actions minimize the harmful consequences of injures. The most important organizational models are the sevendimensional Marvin Webster model, the Harrison model, and the three-branch analysis model (ibid); In the present study, we describe the Three-Branch Analysis model:

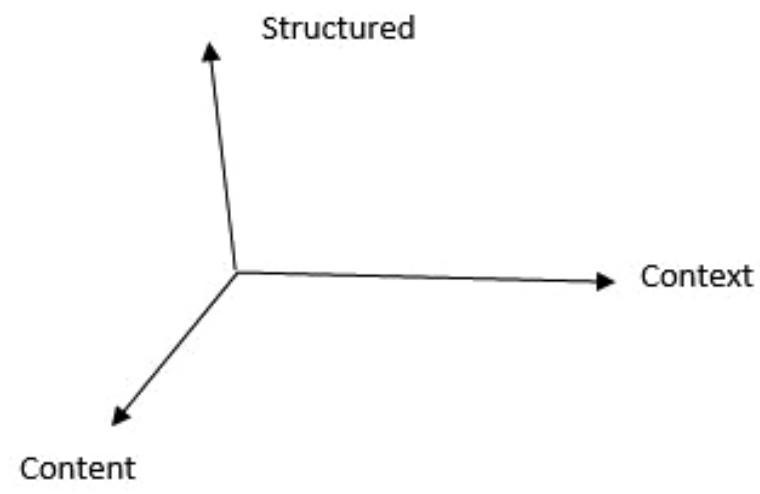

Figure 2. Three-branch analysis model

Reference: Bahramzadeh, Hossein Ali, Amiri, Hooshang, Ghadiri, Ramin. (2015), Pathology of Manpower Management at Mazandaran University of Medical Sciences headquarters based on the Three-Horned Model, Quarterly Journal of Educational Psychology, Issue. 2

Based on this model, the phenomenon of organization and management can be analyzed according to three categories of behavioral, structural and environment factors. Behavioral (content) factors are all factors related to the human resources that make up the content of the organization, such as motivation and job satisfaction. Structural factors include a set of regular relationships governing the internal components of the organization that make up the body, such as organizational structure and rules and regulations. Ultimately, the environment factors include the environment and external conditions that cause behavioral and structural factors [16:100], all elements that make up the structure and content without exception to the environment. No source can be imagined without the environment. Therefore, all organizational events and phenomena can be studied, analyzed in the form of three-branch theory. The model consists of three branches: structure, context and content.
Analysis. In this research, we try to answer these questions. Is there a significant relationship between administrative corruption and factors such as economic status of employees, cultural characteristics of society, organizational characteristics, quality and quantity of laws and individual characteristics of employees? Also, is there a meaningful relationship between the application of control and monitoring methods and the reduction of corruption? What are the most effective methods of controlling? A questionnaire with 20 questions was designed in two sections. The first part was based on the three-branch model in three parts: structure, behavior, and environment. Questions 1-6 of the questionnaire examine the relationship between organizational characteristics and corruption. Questions 7 to 10 of the questionnaire examine the relationship between behavioral-individual and administrative corruption issues and questions 11 to 14 of the questionnaire are to examine the relationship between cultural and economic characteristics of the 
environment and administrative corruption. The second part of the questionnaire, which includes questions 15-20, examines the relationship between methods of control and corruption (Table 1).

Categorization of research questions by subject

\begin{tabular}{|l|l|l|}
\hline $\begin{array}{l}\text { Part I } \\
\text { (based } \\
\text { on a } \\
\text { three- } \\
\text { branch } \\
\text { model) }\end{array}$ & $\begin{array}{l}\text { Branch of } \\
\text { structure }\end{array}$ & $\begin{array}{l}\text { The complexity of the rule; } \\
\text { Failure to inform people of the rules; } \\
\text { The high quantity of the rules; } \\
\text { Lack of benefits for employees; } \\
\text { Lack of effective control mechanisms in the organization; } \\
\text { Lack of efficient reward system. }\end{array}$ \\
\cline { 2 - 4 } & $\begin{array}{l}\text { Branch of } \\
\text { behavior }\end{array}$ & $\begin{array}{l}\text { Lack of conscience; } \\
\text { Prefer individual interests to group interests; } \\
\text { The degree of employee riskiness; } \\
\text { Lack of familiarity with the laws and regulations. }\end{array}$ \\
\cline { 2 - 3 } & $\begin{array}{l}\text { Branch of } \\
\text { environment }\end{array}$ & $\begin{array}{l}\text { Inconsistency between the growth rate of inflation and the growth rate of staff salaries; } \\
\text { The feeling of economic inequality of government employees compared to other sectors; } \\
\text { The degree of relativity in society; } \\
\text { Unconsciousness of the society towards moral standards. }\end{array}$ \\
\hline Part II & $\begin{array}{l}\text { Investigating } \\
\text { the relationship } \\
\text { between methods } \\
\text { of control and } \\
\text { administrative } \\
\text { corruption }\end{array}$ & $\begin{array}{l}\text { Exacerbation of penalties; } \\
\text { Establishing Independent Anti-Corruption Institutions; } \\
\text { Applying Effective Regulations; } \\
\text { Deconstruction of the administrative system; } \\
\text { Effective administrative control; } \\
\text { Efficient financial control system. }\end{array}$ \\
\hline
\end{tabular}

A) Binomial test. Using binomial test we investigated the relationship between all variables of research with the desired variable, namely administrative corruption. It should be noted that the questions for each variable were ranked from 1 to 5 based on the Likert spectrum. This scale of 5 options is divided into positive, negative, and neutral classes. Therefore, the probability of responding to the relationship between the two variables in each question is either opposite or non-orientated will be
0.06. For each of the questions, the binomial test was used in the following way. The results are as follows. Here, the unpopular impact of society on ethical standards on corruption is given as an example.

- zero assumption (HO): Unassailing the community to moral standards do not affect the administrative corruption $(\mathrm{HO}=\mathrm{p} \leq 0.6)$;

- opposite assumption (H1): Unassailing the community to moral standards do affect the administrative corruption $(\mathrm{H} 1=\mathrm{p}>0.6)$.

Table 2

The results of examining related questions through binomial testing

\begin{tabular}{|c|c|c|c|c|c|}
\hline Research variables & $\begin{array}{l}\text { Number of } \\
\text { questions }\end{array}$ & $\begin{array}{c}\text { Ratio } \\
\text { observed }\end{array}$ & $\begin{array}{l}\text { Test } \\
\text { ratio }\end{array}$ & $\begin{array}{c}\text { Meaningful } \\
\text { level }\end{array}$ & $\begin{array}{c}\text { Confirm or reject } \\
\text { variable effects }\end{array}$ \\
\hline $\begin{array}{l}\text { complexity of the rules } \\
0.6=>\text { group } 1 \\
0.6<\text { group } 2\end{array}$ & $\begin{array}{c}0 \\
384\end{array}$ & $\begin{array}{l}.0 \\
1.0\end{array}$ & 0.6 & .000 & $\begin{array}{l}\text { Verify the effect } \\
\text { of the variable }\end{array}$ \\
\hline $\begin{array}{l}\text { the lack of information } \\
\text { to the people } \\
0.6=>\text { group } 1 \\
0.6<\text { group } 2\end{array}$ & $\begin{array}{c}0 \\
384\end{array}$ & $\begin{array}{l}.0 \\
1.0\end{array}$ & 0.6 & .000 & $\begin{array}{l}\text { Verify the effect } \\
\text { of the variable }\end{array}$ \\
\hline $\begin{array}{l}\text { the high quantity of the } \\
\text { rules } \\
0.6=>\text { group } 1 \\
0.6<\text { group } 2\end{array}$ & $\begin{array}{c}0 \\
384\end{array}$ & $\begin{array}{l}.0 \\
1.0\end{array}$ & 0.6 & .000 & $\begin{array}{l}\text { Verify the effect } \\
\text { of the variable }\end{array}$ \\
\hline $\begin{array}{l}\text { the lack of additional } \\
\text { benefits for employees } \\
0.6=>\text { group } 1 \\
0.6<\text { group } 2\end{array}$ & $\begin{array}{c}0 \\
384\end{array}$ & $\begin{array}{l}.0 \\
1.0\end{array}$ & 0.6 & .000 & $\begin{array}{l}\text { Verify the effect } \\
\text { of the variable }\end{array}$ \\
\hline $\begin{array}{l}\text { the lack of effective } \\
\text { control mechanisms in the organization } \\
0.6=>\text { group } 1 \\
0.6<\text { group } 2\end{array}$ & $\begin{array}{c}0 \\
384\end{array}$ & $\begin{array}{l}.0 \\
1.0\end{array}$ & 0.6 & .000 & $\begin{array}{l}\text { Verify the effect } \\
\text { of the variable }\end{array}$ \\
\hline
\end{tabular}


Table 2

\begin{tabular}{|c|c|c|c|c|c|}
\hline Research variables & $\begin{array}{l}\text { Number of } \\
\text { questions }\end{array}$ & $\begin{array}{c}\text { Ratio } \\
\text { observed }\end{array}$ & $\begin{array}{l}\text { Test } \\
\text { ratio } \\
\end{array}$ & $\begin{array}{c}\text { Meaningful } \\
\text { level }\end{array}$ & \begin{tabular}{|c|c|} 
Confirm or reject \\
variable effects
\end{tabular} \\
\hline $\begin{array}{l}\text { the lack of efficient reward system } \\
0.6=>\text { group } 1 \\
0.6<\text { group } 2\end{array}$ & $\begin{array}{c}0 \\
384\end{array}$ & $\begin{array}{l}.0 \\
1.0\end{array}$ & 0.6 & .000 & $\begin{array}{l}\text { Verify the effect } \\
\text { of the variable }\end{array}$ \\
\hline $\begin{array}{l}\text { lack of conscience in Work } \\
0.6=>\text { group } 1 \\
0.6<\text { group } 2\end{array}$ & $\begin{array}{c}0 \\
384\end{array}$ & $\begin{array}{l}.0 \\
1.0\end{array}$ & 0.6 & .000 & $\begin{array}{l}\text { Verify the effect } \\
\text { of the variable }\end{array}$ \\
\hline $\begin{array}{l}\text { the preference of individual interests to group } \\
\text { interests } \\
0.6=>\text { group } 1 \\
0.6<\text { group } 2\end{array}$ & $\begin{array}{c}0 \\
384\end{array}$ & $\begin{array}{l}.0 \\
1.0\end{array}$ & 0.6 & .000 & $\begin{array}{l}\text { Verify the effect } \\
\text { of the variable }\end{array}$ \\
\hline $\begin{array}{l}\text { the degree of employee riskiness } \\
0.6=>\text { group } 1 \\
0.6<\text { group } 2\end{array}$ & $\begin{array}{c}0 \\
384\end{array}$ & $\begin{array}{l}.0 \\
1.0\end{array}$ & 0.6 & .000 & $\begin{array}{l}\text { Verify the effect } \\
\text { of the variable }\end{array}$ \\
\hline $\begin{array}{l}\text { the lack of familiarity with the laws and } \\
\text { regulations, } \\
0.6=>\text { group } 1 \\
0.6<\text { group } 2\end{array}$ & $\begin{array}{c}0 \\
384\end{array}$ & $\begin{array}{l}.0 \\
1.0\end{array}$ & 0.6 & .000 & $\begin{array}{l}\text { Verify the effect } \\
\text { of the variable }\end{array}$ \\
\hline $\begin{array}{l}\text { the lack of fit between the rate of growth of } \\
\text { inflation and the growth rate of employee salaries } \\
\text { group } 1<=0.6 \\
0.6<\text { group } 2\end{array}$ & $\begin{array}{c}0 \\
384\end{array}$ & $\begin{array}{l}.0 \\
1.0\end{array}$ & 0.6 & .000 & $\begin{array}{l}\text { Verify the effect } \\
\text { of the variable }\end{array}$ \\
\hline $\begin{array}{l}\text { the feeling of economic inequality of government } \\
\text { employees compared with other sectors } \\
\text { group } 1<=0.6 \\
0.6<\text { group } 2\end{array}$ & $\begin{array}{c}0 \\
384\end{array}$ & $\begin{array}{l}.0 \\
1.0\end{array}$ & 0.6 & .000 & $\begin{array}{l}\text { Verify the effect } \\
\text { of the variable }\end{array}$ \\
\hline $\begin{array}{l}\text { The degree of kinship in society } \\
\text { group } 1<=0.6 \\
0.6<\text { group } 2\end{array}$ & $\begin{array}{c}0 \\
384\end{array}$ & $\begin{array}{l}.0 \\
1.0\end{array}$ & 0.6 & .000 & $\begin{array}{l}\text { Verify the effect } \\
\text { of the variable }\end{array}$ \\
\hline $\begin{array}{l}\text { Unassailing the community to moral standards, } \\
\text { group } 1<=0.6 \\
0.6<\text { group } 2\end{array}$ & $\begin{array}{c}0 \\
384\end{array}$ & $\begin{array}{l}.0 \\
1.0\end{array}$ & 0.6 & .000 & $\begin{array}{l}\text { Verify the effect } \\
\text { of the variable }\end{array}$ \\
\hline $\begin{array}{l}\text { the intensification of punishment, } \\
\text { group } 1<=0.6 \\
0.6<\text { group } 2\end{array}$ & $\begin{array}{c}0 \\
384\end{array}$ & $\begin{array}{l}.0 \\
1.0\end{array}$ & 0.6 & .000 & $\begin{array}{l}\text { Verify the effect } \\
\text { of the variable }\end{array}$ \\
\hline $\begin{array}{l}\text { The creation of an independent anti-corruption } \\
\text { institutions } \\
\text { group } 1<=0.6 \\
0.6<\text { group } 2\end{array}$ & $\begin{array}{c}0 \\
384\end{array}$ & $\begin{array}{l}.0 \\
1.0\end{array}$ & 0.6 & .000 & $\begin{array}{l}\text { Verify the effect } \\
\text { of the variable }\end{array}$ \\
\hline $\begin{array}{l}\text { Applying Effective Regulations } \\
\text { group } 1<=0.6 \\
0.6<\text { group } 2\end{array}$ & $\begin{array}{c}0 \\
384\end{array}$ & $\begin{array}{l}.0 \\
1.0\end{array}$ & 0.6 & .000 & $\begin{array}{l}\text { Verify the effect } \\
\text { of the variable }\end{array}$ \\
\hline $\begin{array}{l}\text { depoliticizing the bureaucracy } \\
\text { group } 1<=0.6 \\
0.6<\text { group } 2\end{array}$ & $\begin{array}{c}0 \\
384\end{array}$ & $\begin{array}{l}.0 \\
1.0\end{array}$ & 0.6 & .000 & $\begin{array}{l}\text { Verify the effect } \\
\text { of the variable }\end{array}$ \\
\hline $\begin{array}{l}\text { Effective administrative control } \\
\text { group } 1<=0.6 \\
0.6<\text { group } 2\end{array}$ & $\begin{array}{c}0 \\
384\end{array}$ & $\begin{array}{l}.0 \\
1.0\end{array}$ & 0.6 & .000 & $\begin{array}{l}\text { Verify the effect } \\
\text { of the variable }\end{array}$ \\
\hline $\begin{array}{l}\text { Efficient financial control system } \\
\text { group } 1<=0.6 \\
0.6<\text { group } 2\end{array}$ & $\begin{array}{c}0 \\
384\end{array}$ & $\begin{array}{l}.0 \\
1.0\end{array}$ & 0.6 & .000 & $\begin{array}{l}\text { Verify the effect } \\
\text { of the variable }\end{array}$ \\
\hline
\end{tabular}

According to the above table, the results of the relevant questions show that there is a significant relationship between the components in the structural, behavioral, and environmental branches and methods of controlling corruption with administrative corruption.

In other words, the above table states the relationship between the following components (complexity of rules, lack of information, high quantity of the rules, lack of additional benefits for employees, lack of effective control mechanisms in organization, lack of efficient reward system, of conscience in work, preference of individual interests to group interests, degree of employee riskiness, lack of familiarity with laws and regulations, inconsistency between rate of inflation growth and growth rate of 
employee salaries, feeling of economic inequality of government employees compared with other sectors, degree of kinship in society, society's unyielding moral standards, intensification of punishment, creation of an independent anti-corruption institutions, adoption of efficient regulation, depoliticizing the bureaucracy, administrative control effectively, efficient financial control system) with administrative corruption (the dependent variable). It has a significant level of 0.000 or less than 0.5 ; Therefore, the statistical test of the components above is located in the $\mathrm{H} 1$ region and there is a meaningful relationship between the above components with administrative corruption. Also, the $\mathrm{HO}$ assumption is rejected for all components.

B) Friedman Test. Friedman test was used to determine the significance and effect of the components of each structural, behavioral and environmental branches in the three-branch model on administrative corruption and the results are presented in Table 3. It should be noted that the significance and impact of each component of the methods of controlling corruption was also examined separately in accordance with Table 4.

Ranking the importance of effective factors on the emergence of administrative corruption in the Three-branch model

\begin{tabular}{|c|c|c|c|c|}
\hline $\begin{array}{l}\text { Separation of each } \\
\text { branch in the model }\end{array}$ & Variables & $\begin{array}{c}\text { Average rating per } \\
\text { branch }\end{array}$ & $\begin{array}{l}\text { Average rating of } \\
\text { all variables }\end{array}$ & $\begin{array}{l}\text { Rank of each } \\
\text { variables in total }\end{array}$ \\
\hline $\begin{array}{l}\text { The structure } \\
\text { branch }\end{array}$ & $\begin{array}{l}\text { The complexity of the rules } \\
\text { Lack of effective control mechanisms } \\
\text { in the organization } \\
\text { Lack of efficient reward system } \\
\text { Lack of benefits for employees } \\
\text { The high quality of the rules } \\
\text { Failure to inform the rules of the } \\
\text { people }\end{array}$ & \begin{tabular}{|l|}
5.01 \\
4.99 \\
\\
4.04 \\
3.93 \\
3.87 \\
2.79
\end{tabular} & $\begin{array}{l}9.25 \\
9.21 \\
7.35 \\
7.14 \\
6.99 \\
4.90\end{array}$ & $\begin{array}{l}3 \\
4 \\
5 \\
6 \\
7 \\
9\end{array}$ \\
\hline $\begin{array}{l}\text { The behavior } \\
\text { Branch }\end{array}$ & $\begin{array}{l}\text { Lack of conscience } \\
\text { Lack of familiarity with the laws and } \\
\text { regulations } \\
\text { Prefer individual interests to group } \\
\text { The degree of employee riskiness }\end{array}$ & $\begin{array}{l}3.99 \\
2.10 \\
\\
1.95 \\
1.95 \\
\end{array}$ & $\begin{array}{c}11.54 \\
4.54 \\
4.11 \\
4.11 \\
\end{array}$ & $\begin{array}{c}1 \\
10 \\
11 \\
11 \\
\end{array}$ \\
\hline $\begin{array}{l}\text { The environment } \\
\text { branch }\end{array}$ & $\begin{array}{l}\text { Unconsciousness of the society } \\
\text { towards moral standards } \\
\text { The feeling of economic inequality of } \\
\text { government employees compared to } \\
\text { other sectors } \\
\text { Inconsistency between the growth } \\
\text { rate of inflation and the growth rate } \\
\text { of staff salaries } \\
\text { The degree of relativity in society }\end{array}$ & $\begin{array}{l}3.28 \\
2.85 \\
2.57 \\
1.31\end{array}$ & $\begin{array}{l}11.54 \\
10.14 \\
9.21 \\
5.00\end{array}$ & $\begin{array}{l}1 \\
2 \\
4\end{array}$ \\
\hline
\end{tabular}

As it can be seen, the lack of conscientiousness, the feeling of employee economic inequality and the complexity of the laws are in the first, second and third degrees, respectively, in influencing the emergence of administrative corruption. The lack of effective control mechanisms in the organization, the lack of an efficient reward system, the lack of additional benefits for employees, the high quantity of laws, and so on, are at other levels of influence, respectively.

Ranking of Components of administrative Corruption Control Methods

\begin{tabular}{|l|l|c|c|}
\hline \multicolumn{1}{|c|}{ Part II } & \multicolumn{1}{|c|}{ Rating variables } & Average rating & Rating \\
\hline Investigating the & Efficient financial control system & 5.14 & 1 \\
relationship between & Effective administrative control & 5.02 & 2 \\
methods of control and & Establishing Independent Anti-Corruption Institutions & 2.93 & 3 \\
administrative corruption & Exacerbation of penalties & 2.74 & 4 \\
& Deconstruction of the administrative system & 2.61 & 5 \\
& Applying Effective Regulations & 2.56 & 6 \\
\hline
\end{tabular}

As you can see, effective financial control system, | of independent anti-corruption institutions are effective administrative control, and the creation $\quad$ ranked first, second and third, respectively, as the 
most effective methods of controlling corruption. Also, other components include the intensification of penalties, the transformation of the administrative system and the application of effective regulations in the next rank.

Conclusion. According to the findings of this research, we believe that administrative corruption affects as much as economic, social, political, judicial and cultural systems in each country; has negative effects on the legitimacy of the political system, the efficiency of the administrative system, and the country's growth and development. Corruption investigations also show that this phenomenon becomes more complex every day, and it is also indicative of the importance of adopting comprehensive solutions to combat it. It should be noted that effective treatment of corruption in each country requires the recognition of its existence by the people and government officials.

Therefore, in the present study, a set of the most important causes of the emergence of administrative corruption based on the three-branch model of organizational pathology theory in the provinces of Tehran and the most effective methods for controlling corruption have been presented. Based on the results of the research, the most important causes of corruption are based on the three-branch model in the behavior and environment field and then in the structure branch:

1. Lack of conscientiousness and unyielding society towards ethical standards (behavior and environment branch)

2. The feeling of economic inequality of government employees compared to other sectors (environmental branch)

3. The complexity of the rules (structure branch)

4. Lack of effective control mechanisms in the organization (branch structure)

5. Lack of efficient reward system (branch structure)

According to Table 4, the most effective methods of controlling corruption are as follows:
1. Efficient financial control system

2. Effective administrative control

3. Establishing Independent Anti-Corruption Institutions

4. Exacerbation of penalties

5. Dismissal of the administrative system

6. Applying Effective Regulations

Based on this, we will propose solutions to fight the corruption of the administrative system and reform the system:

1. Systematic financial systems through their upgrade

2. Monitoring on the wealth of government employees and their families

3. Strengthen institutions and regulatory bodies such as the inspection agency and their use of information systems

4. Remove the terms of commodity multiplicity, remove rents and exclude grounds

5. Public access to government information and encouragement of employees and citizens to disclose corruption and reward for revealing person.

6. Create grounds for public opinion, NGO and media to monitor the functioning of the administrative system

7. Press freedom and immunity in the disclosure of corruption

8. Reforming the methods and mechanisms of encouragement and punishment in the administrative system

9. Reforming the administrative system by reforming its structure and rules and removing redundant provisions

10. Modifying the rules for the recruitment and selection of employees and directors in the administrative system

11. Creating and developing an e-government mechanism

12. Performing cultural and educational measures in the area of denouncing administrative offenses.

\section{REFERENCES}

1. Abbas Zadegan, Seyed Mohammad (2004) Corruptionю Tehran.

2. Abbas Zadeh, Hassan (2010) Complicating Human Resource Management. Oil Industry, 12, 89-112.

3. Afzali, Abdul Rahman (2011) Administrative corruption and its impact on development. Causes, consequences and solutions. International Law Journal. vol.24, 45.

4. Bahramzadeh, Hossein Ali, Amiri, Hooshang, Ghadiri, Ramin. (2015) Pathology of Manpower Management at Mazandaran University of Medical Sciences headquarters based on the Three-Horned Model. Quarterly Journal of Educational Psychology, 2, 59-82.

5. Goldthorpe, John E. (1991) Sociology of Third World Countries, Astan Quds Razavi Publishing.

6. Khalfkhani, Mehdi (2010) Social Approach in Developing Corruption Measurement Indicators, ScientificSpecialized Quarterly of Assessment Knowledge (National Inspection Organization), vol.2, iss. 3.

7. Khodadad Hosseini, Seyyed Hamid and Mohsen Farhadinejad (2001) Corruption Investigation and its Control Methods. Modares Quarterly, 1. 
8. McFillen, J. M, Deborah, A, ONeil, William, K, Blazer \& Glenn H, Varney. (2013) Organizational Diagnosis: An Evidence-based Approach. Journal of Change Management, vol.13, 2, 223-246.

9. Qarani, Mohammad et al. (2010) Analysis of Corruption Relationship with Good Governance Principles and Its Effectiveness from Organizational Culture (Case Study: Corruption). Proceedings of the Conference on Promoting Occupational Health, Zaman.

10. Rabiei, Ali (2004) Long Live Corruption. Tehran.

11. Rafi Pour, Faramarz (2000) Development and Contradiction. Tehran.

12. Rafi Pour, Faramarz (2009) Social Cancer Corruption. Tehran.

13. Rahimi, H, Siadat, A, Hoveida, R, Shahin, A, Nasrabadi, H. N, Arbabisarjou, A. (2011) The Analysis of Organizational Diagnosis on Based six Box Model in University. Higher Education Studies, 1, 84-92.

14. Shafizadeh, Hamid (2010) Promotion of Culture and General Education to Confront Corruption. ScientificSpecialized Quarterly of Assessment Knowledge (National Inspection Organization), vol.2, iss. 3.

15. Shokrallahi, Masoud (1999) Capacity building for the health of the administrative system, conference of the administrative and development system. Tehran.

16. Tavakoli Darestani, Shaghayegh and Saeed Shahbaz Moradi. (2008) Pathology of Human Resources Management with the Purpose of Improvement and Development. Quarterly Journal of Management and Human Resources in Oil Industry, 4.

17. URL: http://www.entekhab.ir/fa/news/139643.

18. URL: http://www.shomanews.com/fa/news/813569/2016.

19. URL: http://www.asriran.com/fa/news/447291.

20. Zakeri Pour, Gholamreza, Reza Gholi, Fahimeh, Ahmad Abadi, Ahmad. (2011), Human Resources Pathology of fateb in order to Improving Development. Development Quarterly, 22.

Поступила в редакцию: 20 апреля 2018 г. Принята к печати: 10 июля 2018 г. 